\title{
(2) OPEN ACCESS \\ COVID-19 infection in the palatine tonsil tissue and detritus: the detection of the virus compartment with RT-PCR
}

\author{
Hamsu Kadriyan, ${ }^{1}$ Bayu Tirta Dirja, ${ }^{2}$ Dewi Suryani, ${ }^{2}$ Didit Yudhanto ${ }^{1}$
}

\begin{abstract}
'Otolaryngology Head and Neck Surgery, Faculty of Medicine, Mataram University, Mataram, Nusa Tenggara Barat, Indonesia ${ }^{2}$ Microbiology, Mataram University Faculty of Medicine, Mataram, Nusa Tenggara Barat, Indonesia
\end{abstract}

Correspondence to

Dr Hamsu Kadriyan;

hamsu@unram.ac.id

Accepted 30 January 2021

Check for updates

(c) BMJ Publishing Group Limited 2021. Re-use permitted under CC BY-NC. No commercial re-use. See rights and permissions. Published by BMJ.

To cite: Kadriyan H, Dirja BT, Suryani D, et al. BMJ Case

Rep 2021;14:e239108.

doi:10.1136/bcr-2020-

239108

\section{SUMMARY}

Two patients suffering from chronic recurrent tonsillitis were reported. The first patient was confirmed infected with COVID-19, 3 weeks prior to tonsillectomy. The detritus and tonsil specimen were further analysed through real-time PCR (RT-PCR) and revealed amplification of the fragment $\mathrm{N}$ and ORF1ab genes of SARS-CoV-2. The second patient had a negative IgM and positive IgG antibody for COVID-19; however, the nasopharyngeal swab indicated negative for SARSCoV-2. Tonsillectomy was performed 2 weeks after the swab; the tonsil specimen was analysed through RT-PCR and revealed amplification of the N2 and RdRp gene of SARS-CoV-2. According to both results, the presence of the SARS-CoV-2 gene remains to be detected in tonsil and/or detritus after 2-3 weeks after recovery. Hence, it is suggested that it is necessary to use adequate protection when performing tonsillectomy on early recovered patients with COVID-19. Furthermore, tonsillectomy would be more advisable to be performed after the fourth week after recovery from COVID-19.

\section{BACKGROUND}

Laboratory diagnosis to confirm COVID-19 is routinely conducted from clinical specimen such as a nasopharyngeal swab, oropharyngeal swab or bronchoalveolar lavage. Viral load of virus detected from the upper respiratory tract is known to be at its peak on the fourth to sixth day after the initial symptoms emerge. The viral load of COVID-19 in the nasopharyngeal swab is known to be higher compared in the oropharyngeal swab; however, when a throat washing was performed, the result was otherwise. ${ }^{1}$ Hence, this should be further investigated for a better understanding of the mechanism.

During the COVID-19 pandemic, several protocols in otorhinolaryngology recommend postponing any elective procedure, especially ones involving the respiratory tract, except for emergency cases. This is due to the potential transmission that this procedure harbours through droplets and aerosol. As there is uncertainty as to when the pandemic would end, therefore, the guideline has been adjusted according to the condition of a specific region and in accordance with the national guidelines. Several of the adjustments, particularly in the otorhinolaryngology in Indonesia, is that operative procedure could be performed after screening patients for COVID19 , with a minimal approach of screening through a routine rapid test. The procedure is performed using the needed safety measures, along with the use of appropriate personal protective equipment (PPE) for doctors and medical staff. This is to minimise the risk of virus transmission to healthcare workers. $^{2-4}$

Tonsillectomy is a routine procedure performed by an otorhinolaryngologist ${ }^{5}$; therefore, the presence of SARS-CoV-2 in the tonsil and detritus should be confirmed. Hence, further study on this topic is necessary.

It has been reported that the $\operatorname{IgG}$ of patients who have recovered from COVID-19 persists after 3 weeks, whereas the IgM level would decrease gradually after the laboratory confirmation with RT-PCR. However, patients with current illness of COVID-19 would have positive IgG and IgM detected in the blood. ${ }^{6}$ According to the previous Indonesian Ministry of Health Guidelines, the recovery criteria for COVID-19 are when patients have negative results in two consecutive examinations with the nasopharyngeal/oropharyngeal swab with real-time PCR (RT-PCR). However, in the current guidelines, it has been adjusted to only one negative result. ${ }^{7}$

In the case of patients with chronic tonsillitis that requires tonsillectomy procedure but have previously recovered from COVID-19, according to the current national guidelines, analysis is therefore required to prove whether or not SARS-CoV-2 is detected in the operative specimen. In addition, limited study has been conducted on the presence of SARS-CoV-2 in the tonsil and detritus specimen.
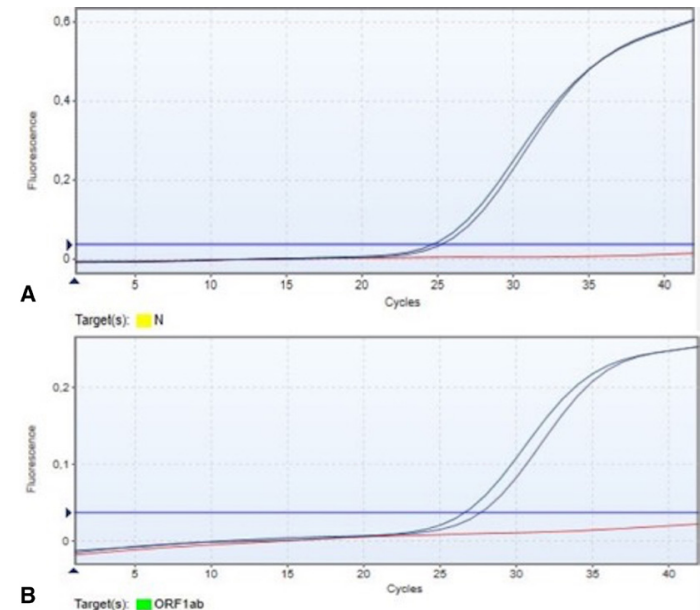

Figure 1 (A) Expression of the N gene; (B) ORF1ab gene from detritus first patient. 


\section{CASE PRESENTATION}

\section{Case 1}

A 26-year-old woman presented with recurrent sore throat that has occurred six times within the previous year. In the past 5 years, this symptom occurred at least three times a year. Findings from physical examination include enlarged tonsils (T3-T3) and detritus accumulation in the tonsillar crypts. Based on the findings from history taking and physical examination, the patient was later diagnosed with chronic recurrent tonsillitis, and according to the American Academy of Otolaryngology Head and Neck Surgery (AAOHNS), a tonsillectomy procedure is recommended. ${ }^{8}$ However, as this patient was admitted during the COVID-19 pandemic, therefore, the procedure was postponed. Two months later, the patient was readmitted to the hospital due to similar symptoms. Moreover, identical findings were identified from anamneses and physical examination with the previous hospital visit; however, no enlargement of the lymph node was discovered. Informed consent was provided by the patient for a tonsillectomy procedure.

During the preoperative procedure, a rapid test for IgM and IgG for the screening of COVID-19 was performed. The result was reactive for both IgG and IgM antibody against COVID-19. Following to the national guideline on a suspected COVID-19 case, therefore, a nasopharynx and oropharynx swab test was conducted to identify SARS-CoV-2 by RT-PCR. The result came out positive. Therefore, the patient underwent quarantine and received treatment for COVID-19. After 3 weeks or approximately 24 days postlaboratory confirmation of COVID-19, the patient visited the hospital to confirm she had recovered from COVID-19. This was confirmed through a nasopharyngeal/ oropharyngeal swab test procedure with two consecutive negative results with the test conducted 3 days apart.

Prior to the preoperative procedure, rapid IgG and IgM for COVID-19 were performed, resulting in a positive result for IgG and a negative result for IgM antibody for COVID-19. Routine blood test and chest X-ray were within normal range. The tonsillectomy procedure was conducted a day after admission to the hospital and was performed under general anaesthesia using the encapsulated dissection approach. All medical workers performing the procedure used appropriate level 3 PPE. The operation went well with no complications.

\section{Case 2}

A 19-year-old man presented with enlarged tonsils and with a complaint of recurring sore throat for the last 3 years, with at least three episodes. Clinical findings from the physical examination were enlarged tonsil (T3-T3) with deep tonsillar crypts. For this case, using the AAOHNS guideline, a tonsillectomy procedure was also recommended. ${ }^{8}$ The preoperative procedure includes a rapid test for COVID-19. The result was positive for IgG and negative for IgM antibody for COVID-19. The patient was referred to the Mataram University Hospital COVID-19 Laboratory Centre to undergo nasopharyngeal and oropharyngeal swabs for the detection of SARS-CoV-2, and later the patient was confirmed to have a negative result. Two weeks after the COVID-19 laboratory test, the tonsillectomy procedure was performed. Prior to surgery, a routine laboratory and chest X-ray were found within normal limits. A similar tonsillectomy procedure was done similar to the first patient.

\section{INVESTIGATION}

Both patients agreed to have their tonsil specimen analysed further by signing an informed consent. To determine the

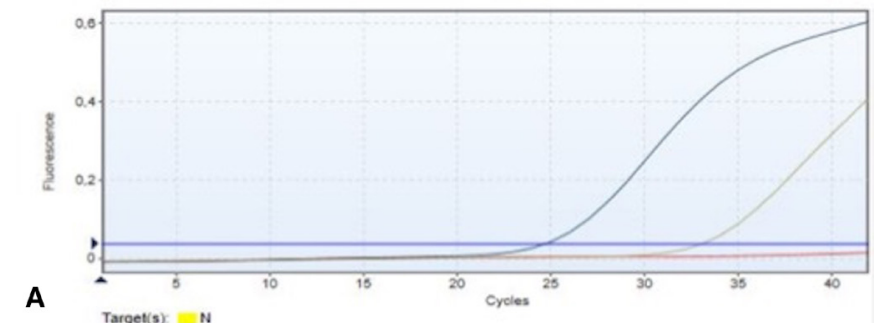

A

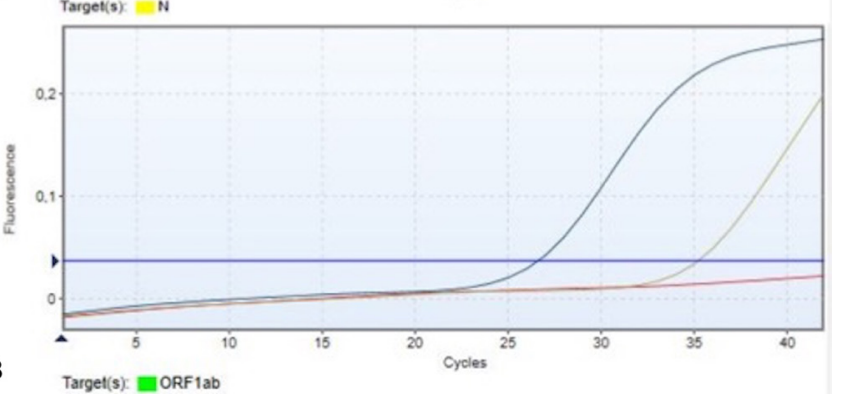

Figure 2 (A) Expression of the $\mathrm{N}$ gene; (B) ORF1ab gene from the tonsil tissue of the first patient.

detection of SARS-CoV-2 in the tonsil and detritus, RT-PCRbased analyses were performed. In the first patient, the postsurgery specimens of the tonsil and detritus were evaluated. The tonsil specimen was placed in a sterile specimen container with $\mathrm{NaCl}$ 0.9\%. RNA extraction of tonsil specimen was conducted within 3 hours after surgery. Three specimens were extracted: tonsil, blood and detritus. Furthermore, an RT-PCR was conducted to identify the presence of SARS-CoV-2 gene fragments in each specimen. The RT-PCR reagent kit used for this specimen was Liferiver by Shanghai ZJ Bio-Tech (LOT number P20200402). RT-PCR was performed according to the reagent protocol and was performed in Rotor-GeneQ (Qiagen). The SARS-CoV-2 gene amplified in this kit was $\mathrm{N}$ gene and ORF1ab gene. The specimen was considered positive for SARS-CoV-2 if two gene fragments were amplified with the Cycle threshold $(\mathrm{Ct})$ value of below 40. Both clinical samples of the tonsil (Ct value of Orf1ab gene 27.69 and $\mathrm{Ct}$ value of $\mathrm{N}$ gene 25.26) and detritus (Ct value of Orf1ab gene 35.25 and $\mathrm{Ct}$ value of $\mathrm{N}$ gene 33.06) were positive for SARS-CoV-2 as both the N and Orf1ab were amplified on both clinical specimens (graphic of RT-PCR curve of the respective clinical samples is illustrated in figures 1 and 2).

The tonsil specimen for the second patient was handled similarly with that for the first patient and was further analysed for the presence of SARS-CoV-2 genes. Samples were sent to the laboratory to be extracted and were later analysed using the LiliF COVID-19 Real-Time RT-PCR kit (Lot number H215051253) run in Rotor-GeneQ (Qiagen). The procedure was performed according to the manufacture's protocol. Interpretation of a positive result using this kit was if at least any two of the RdRp gene, $\mathrm{N}$ gene and $\mathrm{E}$ gene were amplified with a $\mathrm{Ct}$ value below 35. A SARS-CoV-2 gene fragment was detected in the tonsil specimen with the amplification of $\mathrm{N}$ gene (Ct value 24.13) and RdRp gene (Ct value 25.88) (figure 3). The detritus was not found from this patient; hence, the analysis was not performed for RT-PCR.

\section{TREATMENT}

Both patients were able to conduct daily activities 3 days after the procedure. However, as the Ct value of RT-PCR was positive, both patients were suggested to self-isolate for 10 days. Medication given to patients were antibiotics and analgesic. 


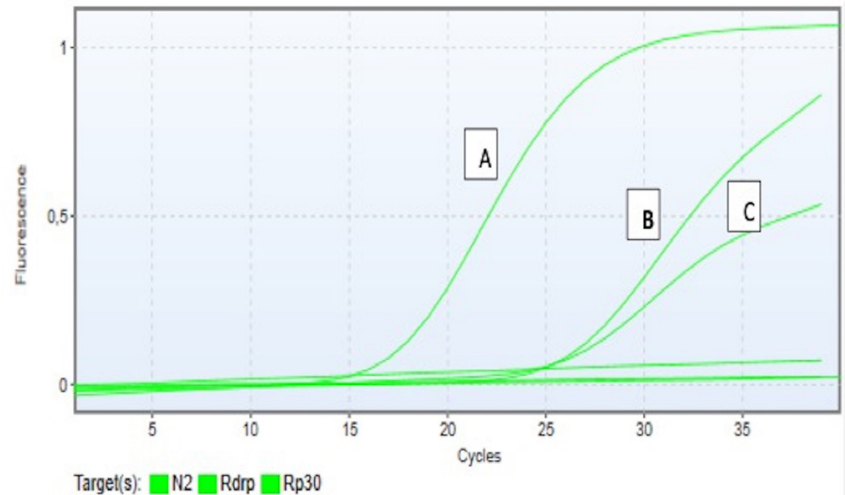

Figure 3 Expression of RP gene (A), N gene (B) and RdRP gene (C) from the tonsil tissue of the second patient.

\section{OUTCOME AND FOLLOW-UP}

The postoperation suture was recovered within 14 days for both patients. No other diseases/complications were reported by both patients, and no symptoms of fever, sore throat and bleeding existed.

\section{DISCUSSION}

A study by Sara et al has categorised the treatment of adenotonsillitis during the COVID-19 pandemic into prioritised and non-prioritised cases according to the severity of the sign and symptoms observed in patients. Several considerations for the case to be a prioritised case were severe sleep apnoea, cochlear implant, otitis media effusion and speech difficulty. According to these criteria, they have identified 47 patients among 358 patients to be included as a prioritised operative case. ${ }^{9}$ More recent guidelines have allowed elective surgery to be performed with extra precaution to maintain protection at a high level for both patients and medical staff involved in the surgery. ${ }^{2}$ Therefore, a tonsil surgery is possible during the COVID-19 pandemic with sufficient preparation and safety measures.

The aforementioned result suggests that the SARS-CoV-2 gene remains present in the tonsil and detritus specimen although undetected in the nasopharynx swab. However, further study is required to explain the mechanism. The SARS-CoV-2 gene has also been identified in other specimens such as faeces and has been reported to persist until 7 days after a nasopharyngeal swab was negative. ${ }^{10}$ It has been proposed by the previous study that the presence of the SARS-CoV-2 gene fragment in other clinical specimens, such as the oesophagus, gaster, duodenum and rectum, is facilitated by the ACE- 2 receptor. ${ }^{11}$ This was also supported by another study that was able to identify SARS-CoV-2 in the central nervous system (CNS). ${ }^{12}$ It has been identified that the ACE-2 receptor level in the tonsil is lower compared with lung, CNS and ileum, that is, $1 / 3,1 / 4$ and $1 / 5$, respectively. ${ }^{13}$ Hence, it has been presumed that the presence of SARS-CoV-2 in the tonsil is asymptomatic or mild.

To date, there has not been any study on the presence of SARS-CoV-2 in the tonsil and detritus from a clinical specimen post-tonsillectomy. According to the pathophysiology of the IgG and IgM of SARS-CoV-2 in the host, the level of IgG antibody begins to rise in the second week and can last for 6 weeks from the onset of infection. However, IgM would start to rise at the end of the first week and gradually declines in the third week. RT-PCR has the potential to detect SARS-CoV-2 since the first week of infection and would be better detected in the second week, then decline after the third week; however, the virus may persist until the fourth week. ${ }^{6}$

According to the aforementioned explanation, our case, where the IgG remained detected and IgM undetected with two consecutive negative results with RT-PCR, would suggest that the patient was in the recovery phase of COVID-19. Nevertheless, the SARS-CoV-2 gene in the tonsil and detritus specimen of this patient post-tonsillectomy was detected. Whether or not the SARS-CoV-2 gene detected in the clinical specimen of this patient has the potential for transmission remains inconclusive. It was proposed that either remanence of gene fragments of SARS-CoV2 was detected or possibly the whole virus gene. Further study is needed to gain a more conclusive explanation. However, for safety measures for patient and medical staff, the potential of virus transmission should not be excluded until further study that would better explain the potential of transmission of SARS-CoV-2 that remains in tonsil and detritus specimen is conducted.

Several approaches to confirm the transmissibility of the virus are through virus culture, immunofluorescent detection and genome sequence. A positive virus culture result was known to be associated with prolonged virus shedding and hence would confirm the transmissibility of the virus detected from clinical specimen. Confirmation of the virus could also be performed through immunofluorescent approach and whole genome sequence. Furthermore, a whole genome sequence would be necessary to identify the presence of the same virus overtime and also to confirm the presence of the same virus from different clinical samples obtained from the same patient. ${ }^{14} 15$

Therefore, based on this finding, it would be advisable for the surgery team to perform tonsillectomy procedure with the necessary PPE required for sufficient protection (at least PPE level 3). Moreover, it is also advisable to not conduct or minimise any procedure that would cause aerosol exposure, such as electrocautery, as this may cause virus particles to splatter in the air and harbour the risk of transmission towards medical team. This suggestion is similar to the study by Carr et al, which has reported that the use of electrocautery in tonsillectomy procedure with surgical smoke evacuation system would decrease the number of particles surrounding the surgeon's airway to approximately 1661 particles $/ \mathrm{cm}^{3}$ compared with 8208 particles $/ \mathrm{cm}^{3}$ without the system. ${ }^{16}$

The new guidelines of COVID-19 released by the Indonesian Ministry of Health recommends that the criteria of recovery from COVID-19 be confirmed by a single negative nasopharynx swab by RT-PCR. However, our findings have identified the presence of SARS-CoV-2 in the patients' tonsils. Therefore, it would be advisable to postpone any elective procedure for at least 4 weeks from the first negative RT-PCR confirmation of COVID19. This is supported by the detection of SARS-CoV-2 gene in the tonsil and detritus of the patient after the 25 th day postinfection; moreover, it has also been reported that SARS-CoV-2 remains detectable in faeces after the seventh day of a negative result from nasopharynx swab, ${ }^{10}$ as well as the virus could persist until the fourth weeks. ${ }^{6}$

Our cases have detected the presence of SARS-CoV2 in the tonsil and detritus clinical specimen post-tonsillectomy after the 25 th day from the first RT-PCR confirmation. According to these results, it is also suggested that tonsillectomy procedures during this pandemic should be performed under strict measures, even if the patient has been confirmed recovered from COVID-19, which can be confirmed by a negative result of the nasopharyngeal swab and RT-PCR test. If a tonsillectomy procedure is necessary to be performed, a level 3 PPE is required for 
an operative procedure under these circumstances. However, it is more advisable to postpone the surgery at least 4 weeks after recovery from COVID-19.

\section{Patient's perspective}

First patient: I am surprised and in denial after discovering that I still had a positive result of COVID-19 in the postoperative clinical specimen and was concerned if I would have to be quarantined again, but I am relieved that I was able to selfisolate in the comfort of my home by adhering to the isolation measures and protocol.

Second patient: I am surprised after knowing the tonsil clinical specimen finally detected the SARS-CoV-2, although in the other specimens were negative. However, I was relieved that the surgery went well and the recovery was a smooth process with no complication either.

\section{Learning points}

- Tonsillectomy procedure during the COVID-19 19 pandemic may still be performed with extra caution and the use of personal protective equipment level 3.

- Although the patients have been confirmed recovered from COVID-19 through a negative result of nasopharynx swab and RT-PCR analysis, the SARS-CoV2 gene remains detected in the tonsil and detritus from the patients' clinical specimen.

- To minimise the risk of transmission, the tonsillectomy procedure should be postponed at least 4 weeks after recovery from COVD-19.

Acknowledgements The authors extend their gratitude to Lalu Husni, rector of Universitas Mataram, who provided the facility of real-time PCR in Universitas Mataram Hospital and made it possible for the confirmation of the COVID-19 case for patients.

Contributors HK and DY drafted and conceptualised the manuscript. BTD and DS performed the real-time PCR analysis. DS translated and proofread the manuscript. HK, DY, BTD and DS approved the final manuscript.

Funding The authors have not declared a specific grant for this research from any funding agency in the public, commercial or not-for-profit sectors.

Competing interests None declared.

Patient consent for publication Obtained.
Provenance and peer review Not commissioned; externally peer reviewed.

Open access This is an open access article distributed in accordance with the Creative Commons Attribution Non Commercial (CC BY-NC 4.0) license, which permits others to distribute, remix, adapt, build upon this work non-commercially, and license their derivative works on different terms, provided the original work is properly cited and the use is non-commercial. See: http://creativecommons.org/ licenses/by-nc/4.0/.

\section{REFERENCES}

1 Mawaddah A, Gendeh HS, Lum SG, et al. Upper respiratory tract sampling in COVID-19. Malays J Pathol 2020;42:23-35.

2 Lammers MJW, Lea J, Westerberg BD. Guidance for otolaryngology health care workers performing aerosol generating medical procedures during the COVID-19 pandemic. J Otolaryngol Head Neck Surg 2020;49:1-8.

3 Thamboo A, Lea J, Sommer DD, et al. Clinical evidence based review and recommendations of aerosol generating medical procedures in otolaryngology - head and neck surgery during the COVID-19 pandemic. J Otolaryngol Head Neck Surg 2020;49:1-14.

4 Topf MC, Shenson JA, Holsinger FC, et al. Framework for prioritizing head and neck surgery during the COVID-19 pandemic. Head Neck 2020;42:1159-67.

5 Verma R, Verma RR, Verma RR. Tonsillectomy-Comparative study of various techniques and changing trend. Indian J Otolaryngol Head Neck Surg 2017;69:549-58.

6 Jin Y, Wang M, Zuo Z, et al. Diagnostic value and dynamic variance of serum antibody in coronavirus disease 2019. Int J Infect Dis 2020;94:49-52.

7 Kementrian Kesehatan Republik Indonesia. Keputusan Menteri Kesehatan Republik Indonesia Tentang Panduan Pencegahan DAN Pengendalian COVID-19. 2020, 2019. Available: https://covid19.go.id/storage/app/media/Regulasi/KMK No. HK.01.07MENKES-413-2020 ttg Pedoman Pencegahan dan Pengendalian COVID-19.pdf [Accessed 3 Aug 2020].

8 Randel A. AAO-HNS guidelines for tonsillectomy in children and adolescents. Am Fam Physician 2011:84:566-73.

9 Sara T, Pasquale C, Michele G. ENT management of children with adenotonsillar disease during COVID-19 pandemic. ready to start again? Int J Pediatr Otorhinolaryngol 2020:1-4.

10 Chen Y, Chen L, Deng Q, et al. The presence of SARS-CoV-2 RNA in the feces of COVID-19 patients. J Med Virol 2020;92:833-40.

11 Xiao F, Tang M, Zheng $X$, et al. Evidence for gastrointestinal infection of SARS-CoV-2. Gastroenterology 2020;158:1831-3.

12 Baig AM, Khaleeq A, Ali U, et al. Evidence of the COVID-19 virus targeting the CNS: tissue distribution, host-virus interaction, and proposed neurotropic mechanisms. ACS Chem Neurosci 2020;11:995-8.

13 Ziegler CGK, Allon SJ, Nyquist SK, et al. SARS-CoV-2 receptor ACE2 is an interferonstimulated gene in human airway epithelial cells and is detected in specific cell subsets across tissues. Cell 2020;181:1016-35.

14 van Kampen JJ, van de Vijver DA, Fraaij PLA. Shedding of infectious virus in hospitalized patients with coronavirus disease-2019 (COVID-19): duration and key determinants. medRxiv 2020:1-28.

$15 \mathrm{Vi} \mathrm{G}$, Morris CP, Wohl S. Repeat COVID-19 molecular testing: correlation of SARSCoV-2 culture with molecular assays and cycle Thresolds. Clin Infect Disesase 2020.

16 Carr MM, Patel VA, Soo J-C, et al. Effect of electrocautery settings on particulate concentrations in surgical plume during tonsillectomy. Otolaryngol Head Neck Surg 2020;162:867-72.

Copyright 2021 BMJ Publishing Group. All rights reserved. For permission to reuse any of this content visit

https://www.bmj.com/company/products-services/rights-and-licensing/permissions/

BMJ Case Report Fellows may re-use this article for personal use and teaching without any further permission.

Become a Fellow of BMJ Case Reports today and you can:

- Submit as many cases as you like

- Enjoy fast sympathetic peer review and rapid publication of accepted articles

- Access all the published articles

- Re-use any of the published material for personal use and teaching without further permission

Customer Service

If you have any further queries about your subscription, please contact our customer services team on +44 (0) 2071111105 or via email at support@bmj.com.

Visit casereports.bmj.com for more articles like this and to become a Fellow 